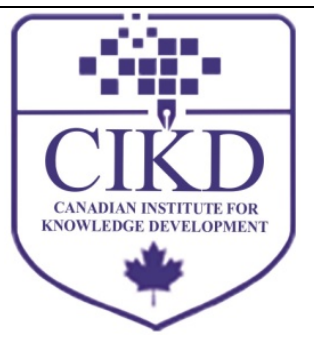

\title{
Factors Influencing Entrepreneurial Intentions of Slovak Youth Growing up in Cities and in Villages
}

\author{
Stanislav Kološta ${ }^{{ }^{*}}$, Filip Flaška ${ }^{1}$, Gabriela Nedelová ${ }^{1}$, Alena Kaščáková ${ }^{1}$, \\ Torbjørn Årethun ${ }^{2}$, Jon Gunnar Nesse ${ }^{2}$ \\ ${ }^{1}$ Matej Bel University, Tajovského 10, 975 90, Banská Bystrica, Slovak Republic \\ ${ }^{2}$ Western Norway University of Applied Sciences, Box 133, N-6851 Sogndal, Norway
}

\begin{tabular}{l} 
Keywords: \\
Entrepreneurial Intentions, \\
Factors, Youth, \\
Entrepreneurship \\
\hline Received \\
09 May 2018 \\
Received in revised form \\
01 August 2018 \\
Accepted \\
23 August 2018 \\
\hline
\end{tabular}

Correspondence:

stanislav.kolosta@umb.sk

\begin{abstract}
Entrepreneurial intentions and factors influencing them are important in explaining and often triggering the entrepreneurial activity resulting in establishing new business and enabling to employ other people. This is especially important in category of young people. This study tries to explain common and different threats in entrepreneurial education, individual and contextual factors as variables explaining entrepreneurial intentions of youth growing in two different environments - city and village. This study also investigates if young people are willing to start their carrier in place of their birth. Data were collected in two rounds of voluntary anonymous electronic surveys among students, 537 respondents, who have finished their high-school studies. The principal component and regression analysis were applied. The dependent variable, entrepreneurial intentions, is constructed by combining items that differently measure an individual's intentions to become an entrepreneur. The independent variables consist of measures for entrepreneurial education, social and cultural capital as well as individual factors as gender, career anchors, proactive personality and others.
\end{abstract}

During the last two decades, entrepreneurship has gained increasing attention worldwide, both in research and in politics. Entrepreneurship, or the creation of new enterprises, is an important part of business dynamics. Governments and local communities across the world have 
recognized that a key to building prosperity and stimulating regional growth is fostering entrepreneurship among their people especially youth (Sharma \& Madan, 2014). High degree of entrepreneurship is required in order to create new and alternative jobs, and to avoid loss of population from less developed regions. Supporting and promoting the entrepreneurship is also an important part of national policies dealing with regional development and entrepreneurship education.

The identification of individual's entrepreneurial intentions (EI) is important (Fayolle \& Liñán, 2014) because it facilitates private investment and public funding to be most efficiently channeled toward those who will start new businesses and thereby create values for individuals and society (Douglas, 2013). EU's initiatives "Youth on the Move", and "Agenda for new skills and jobs" unleashing the potential of young people, and puts young people at the center of the EU framework agenda. Learning institutions should pay careful attention in designing their entrepreneurship education curriculum, and that entrepreneurship training should focus on enhancing student's individual entrepreneurial orientation ability and increasing their EI (Koe, 2016).

Previous studies (Martin, McNally, \& Kay, 2013; Pittaway \& Cope, 2007; Souitaris, Zerbinati, \& Al-Laham, 2007) showed a link between entrepreneurial training/education and entrepreneurial intentions to start a new business during university studies. Data from Center of Science and Technology Information of Slovak Republic showed that in 2016, 55\% of high school students in Slovakia did not continue to university studies. These students do not have opportunities to be involved within university entrepreneurial education programs. This was the reason for investigating the relationship between EI and participation in entrepreneurial courses and training for high school students in the final year of their studies. Besides this, our intention was to gain deeper insight into the driving forces behind EI among Slovak youth.

According to Ministry of Agriculture and Rural development of Slovak republic, Slovakia is considered for a rural country with exception of Bratislava metropolitan region. Primary data were collected in three rural regions in central and eastern part of Slovakia with highest longterm unemployment of high-school graduates and weak economic performance - Banská Bystrica, Žilina, and Prešov region (in 2014 regional average GDP in these regions do not reached $73 \%$ of average Slovak regional GDP, and average value of long-term unemployment of high-school graduates in 2015 was $137 \%$ of national average).

The present study tries to explain common and different threats in entrepreneurial education, individual and contextual factors as variables explaining entrepreneurial intentions of youth growing in two different environments - city ${ }^{1}$ and village. We are also investigating, if young people are willing to start their carrier in place of their birth. Previous research have investigated the antecedents of EI (Fini, Grimaldi, Marzocchi, \& Sobrero, 2012; Goethner, Obschonka, Silbereisen, \& Cantner, 2012; Nga \& Shamuganathan, 2010; Ozaralli \& Rivenburgh, 2016; Zellweger, Sieger, \& Halter, 2011). We can find some studies focusing on EI in rural areas (Bao \& Peng, 2016; Elert, Andersson, \& Wennberg, 2015; Rădulescu, Marian,

\footnotetext{
${ }^{1}$ In Slovakia, municipalities with more than 5000 inhabitants are considered as cities. Total number of municipalities is 2927 including 140 cities (only 9 cities have 50 000-100 000 inhabitants; only capital city have more than 100000 inhabitants). Objects of this study were rural regions with the absolute dominance of smaller municipalities.
} 
\& Moica, 2014; Gavrila-Paven, Dobrescu, \& Dobre, 2014; Altinay et al., 2012) but it is rare to find studies targeting youth EI in predominately rural areas in final year of their study (Norwegian study by Nesse, Årethun, Håvold, 2015) when young people are thinking and deciding about their future perspectives when EI could be crucial in running their own business or factors impacting on EI could influence their further academic studies. Findings explaining entrepreneurial education in relationship to EI could focus on possible future changes to improve entrepreneurial education in Slovakia. For decision makers, it could be interesting to know more about current antecedents of Slovak youth's EI, which can provide some implications within domestic policies. In this way, our study makes a contribution to previous EI literature.

\section{Literature Review}

Entrepreneurial intentions belong to the area of cognitive psychology, and are an important individual outcome in the context of career development (Obschonka, Silbereisen, \& SchmittRodermund, 2010). EI are based on Theory of planned behavior (Ajzen, 1991), and are defined as the commitment to start a new business (Krueger, 1993). EI derive from attitudinal variables which are influenced by exogenous factors such as prior entrepreneurial exposure (Krueger, Reilly, \& Carsrud, 2000). In this study, the dependent EI variable is constructed the same way as Nesse et al. (2015) described together with independent variables in Figure 1, which illustrates model construction and contains theoretical background.

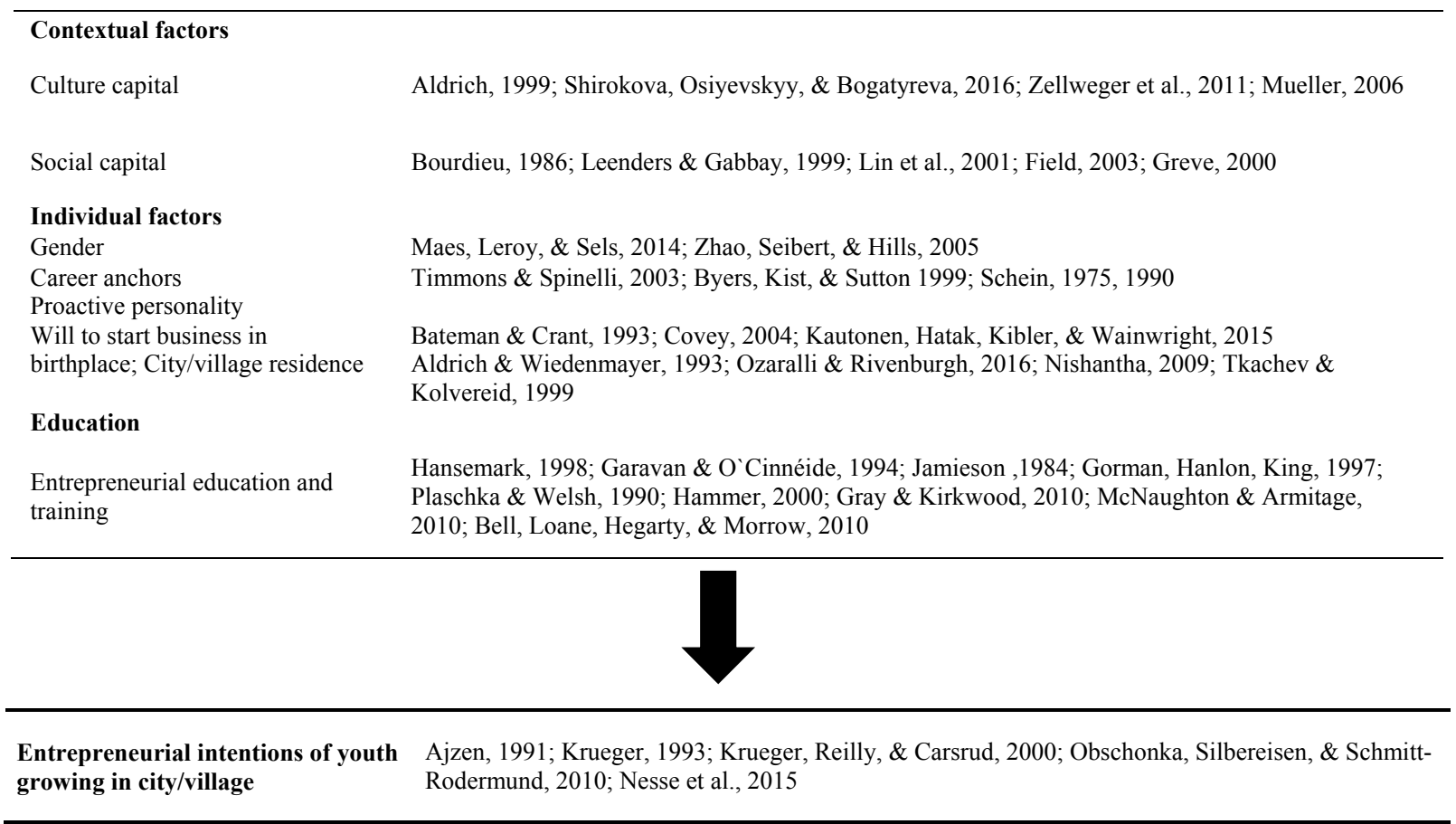

Figure 1. Model construction and theoretical background

Entrepreneurship must be understood as a process (Bygrave, 2004), and researchers have found two main groups of factors that have an impact on this process: contextual and individual factors (Mazzarol, Volery, Doss, \& Thein 1999). In this study, we looked at two main groups of contextual factors: cultural capital and social capital. Cultural capital is the 
values and attitudes gained from one's family, while social capital is the possibility of mobilizing resources from a society to attain ones' goal (Bourdieu, 1986).

Regarding individual factors which could be considered for an individual level of entrepreneurial orientation concept (Robinson \& Stubberud, 2014; originated from Miller, 1983), we used gender, career anchors and proactive personality as the main antecedents of EI. Gender had a direct impact on EI (Zhao et al., 2005). Schein (1990) defines career anchor as a combination of perceived areas of competence, motives, and values that you would not give up. Career anchors mirror our perception of ourselves, and will affect how we evaluate different career alternatives. Based on previous studies (Byers et al., 1999; Schein 1975; Timmons \& Spinelli, 2003), for career anchors of Slovak, youth will be considered: leadership, autonomy, creativity, need for security, and technical-functional competence (realization of professional technical or academic interest).

Bateman and Crant (1993) defined proactive personality as the relatively stable tendency to affect environmental change. Proactive people are those who do not blame circumstances, conditions, or conditioning for their behavior (Covey, 2004). Proactive behavior is intended to identify differences among people to the extent in which they take action to influence their environments. Proactive people can play a significant role in improving their lives and the society they belong to.

As a business-environment variable we used young people who will start their carrier in place of their birth as variable of youth's perception of business opportunities in their birthplace, and city or village residence. The results of Tkachev and Kolvereid's (1999) study indicated that demographic characteristics affected entrepreneurial intentions. Original contribution of this study can be seen also in its focus on common and different threats or factors influencing youth's EI growing in two different environments - city and village. Nishantha (2009) highlights that regional difference is an important factor influencing youth's entrepreneurship. These two variables are also influenced by socio-economic and political conditions of country and region, and positive student's perception of socio-economic and political conditions can support their EI, and vice versa (Aldrich \& Wiedenmayer, 1993; Ozaralli \& Rivenburgh, 2016).

Entrepreneurial training aims primarily at providing students with entrepreneurial motives and attitudes, while traditional education is rigged for the transmission of knowledge and skills from tutors to students (Hansemark, 1998). In this respect, entrepreneurial training will have an indirect impact on entrepreneurial activity, through entrepreneurial intentions. Garavan and O Cinnéide (1994) argue that entrepreneurial education and entrepreneurial training serve two different purposes. The first category is aimed at providing for the participants with theories about factors influencing an individual's entrepreneurial intentions and his/her success rate and the kind of skills required for starting up one's own business. Second category - entrepreneurial training, in particular training that occurs in secondary school, focuses on how to spot good business opportunities, how to value alternative activities such as being a salaried worker or unemployed, and provides practical skills on how to run a small-scale business. Gorman, Hanlon and King (1997) concluded that formal entrepreneurial education will increase entrepreneurial activity and that factors positively correlated to entrepreneurial intentions can be affected by entrepreneurial programmes. Over recent decades, entrepreneurial programmes 
have used process-oriented approaches with a theory-based component integrated into a classowned entrepreneurial business-design (Hammer, 2000; Plaschka, Welsh, 1990). These theoretical assumptions provided us sufficient background for data collection and its assessment.

\section{Methodology}

Data were collected in two rounds of voluntary anonymous electronic surveys among students finishing their high-school studies. There were 537 respondents (students finishing their highschool studies in May 2016 - 251 responses, and in May 2017 - 286 responses). Google questionnaires were distributed among final year students in upper secondary school using their e-mail at school or providing the school's website with a link to the questionnaire. Students who could complete questionnaires during IT-lessons or at home.

Following procedures were applied on the whole sample (Model 1). After that, we divided respondents into two samples: those growing up in cities (Model 2), and those growing up in villages (Model 3).

We constructed the dependent variable Entrepreneurial Intentions (EI) from 5 items in Table 1 as the same way as Nesse et al.'s (2015) scale from 1 "strongly agree" to 5 "strongly disagree". We performed a principal component analysis to check whether it would be appropriate to describe our set of five correlated variables in terms of one or more unobserved variables (factors). In addition, we have estimated the Cronbach's alpha, which is an indicator for the internal consistency (reliability) of a latent variable; the results showed that it is appropriate to aggregate the five items to one EI variable. Cronbach's alpha was .76 (city residence .73; village residence .79) and items have loadings from $54.7 \%$ to $81.6 \%$ of the same factor. We can consider the EI as an indicator of an early phase of an intention to establish an enterprise, since we did not have information about whether the respondents transformed their intentions into action to start a new business. EI is a reliable predictor of entrepreneurial behavior because entrepreneurial behavior is difficult to measure (Wu, 2010).

Table 1

Construction of Dependent Variable EI

\begin{tabular}{ll}
\hline Items & Scale \\
\hline $\begin{array}{l}\text { It is better to have your own company than to work for others } \\
\text { I can imagine to establish own company }\end{array}$ & $\begin{array}{l}5 \text { point ordinal scale } \\
5 \text { point ordinal scale }\end{array}$ \\
$\begin{array}{l}\text { I would start my own company even if the chances of economic losses were } \\
\text { considerable }\end{array}$ & 5 point ordinal scale \\
$\begin{array}{l}\text { Having own company involves a lifestyle that suits me well } \\
\text { Operate own company }\end{array}$ & 5 point ordinal scale \\
\hline Entrepreneurial Intentions (EI) - dépendent variable & 5 point ordinal scale \\
\hline
\end{tabular}

We have two main groups of independent variables - contextual and individual factors. Besides them we conclude into our research business-environment and education characteristics. These variables are described in Table 2. 


\section{Contextual Factors}

\section{Cultural and Social Capital}

The professions of the respondents' parents are used to measure cultural capital while a respondent's evaluation of the possibility of mobilizing the support of family and friends to find new business opportunities are used as proxies for social capital.

\section{Individual Factors}

Gender - The survey included questions on demographic characteristics of gender.

Career anchors - we used Schein's (1975) five original career anchors which were included in the model based on questions on how important these factors are in the respondents' career decisions. We used desire to become a leader, autonomy, creativity, security, and technicalfunctional competence which was divided into technical and academic interests.

Proactive personality PAP - The five items suggested by Kickul and Gundry (2002) are included in the PAP construct. These items are shown in Table 2. We performed similar validity and reliability tests for items connected to proactive personality as we did for entrepreneurial intentions. Test showed that it is appropriate to aggregate the five items to one concept called proactive personality. Cronbach's alpha was .74 (city residence .73; village residence .76) and factor loadings were from $63.6 \%$ to $80.3 \%$ of the same factor. The Cronbach's alpha values of EI and PAP were above the .70 threshold and the results indicated that they were considered preferable (Pallant, 2011).

As business-environment variable - we used young people's will to start their carrier in place of their birth as variable of youth's perception of business opportunities in their birthplace. We would like also to know, if city or village residence influence youth's EI.

Entrepreneurial training in high school - Starting and managing one's own quasi-firm as part of education at high school. The quasi-firm could be a joint venture with classmates working together.

Entrepreneurial courses in high school - Entrepreneurial education in high school providing theoretical knowledge in addition to starting and managing a quasi-firm. 
Table 2

Construction of Independent Variables - Definitions and Types

\begin{tabular}{|c|c|c|}
\hline Variable & Definition & Variable type \\
\hline \multicolumn{3}{|c|}{ Contextual factors - cultural and social capital } \\
\hline Self-employed parents & $\begin{array}{l}1=\text { having at least one of the parents self-employed or } \\
\text { owning a business, } \\
0=\text { otherwise }\end{array}$ & Binary \\
\hline $\begin{array}{l}\text { Relatives as } \\
\text { role model }\end{array}$ & $\begin{array}{l}1=\text { respondent having relatives owning } \text { a business, } 0= \\
\text { otherwise }\end{array}$ & Binary \\
\hline Friends as role models & $\begin{array}{l}1=\text { respondent having friends owning a business, } 0= \\
\text { otherwise }\end{array}$ & Binary \\
\hline Other role models & $\begin{array}{l}1=\text { respondent knowing others owning a business, } 0= \\
\text { otherwise }\end{array}$ & Binary \\
\hline Perceived support & $\begin{array}{l}\text { Perceived support from friends/relatives to start an } \\
\text { enterprise }\end{array}$ & 5 point ordinal scale \\
\hline \multicolumn{3}{|l|}{ Individual factors } \\
\hline Gender & $1=$ female, $0=$ male & Binary \\
\hline $\begin{array}{l}\text { Leadership } \\
\text { Autonomy } \\
\text { Creative } \\
\text { Security } \\
\text { Technical specialist } \\
\text { Academic interest }\end{array}$ & $\begin{array}{l}\text { Wishing to become a leader } \\
\text { Favoring independence } \\
\text { Motivated to create something new } \\
\text { Favoring a secure life situation } \\
\text { Having a technical interest } \\
\text { Having an academic interest }\end{array}$ & $\begin{array}{l}5 \text { point ordinal scale, ranging from } 1= \\
\text { very important" to } 5=\text { very unimportant" } \\
\text { for the career choice }\end{array}$ \\
\hline Will to start career in birthplace & $1=$ Yes, $0=$ No & Binary \\
\hline City/village residence & $1=$ Village, $0=$ City & Binary \\
\hline Proactive personality (PAP) & $\begin{array}{l}\text { 1. I enjoy facing and overcoming obstacles to my } \\
\text { ideas } \\
\text { 2. Nothing is more exciting than seeing my ideas turn } \\
\text { into reality } \\
\text { 3. I excel at identifying opportunities } \\
\text { 4. I love to challenge the status quo } \\
\text { 5. I can spot a good opportunity long before others } \\
\text { can }\end{array}$ & $\begin{array}{l}\text { Each item has a } 5 \text { point scale, from } 1= \\
\text { agree completely" to } 5=\text { disagree } \\
\text { completely" } \\
5 \text { items, ranging from } 5-25\end{array}$ \\
\hline \multicolumn{3}{|l|}{ Education } \\
\hline Entrepreneurial course & $1=$ Yes, $0=$ No & Binary \\
\hline Entrepreneurial training & $1=$ Yes, $0=$ No & Binary \\
\hline
\end{tabular}

Many studies have explored an array of factors influencing individuals' intentions to go into business using mainly regression methods (e.g., Bacq \& Alt, 2018; Esfandiar, Sharifi-Tehrani, Pratt, \& Altinay 2017; Gurel et al., 2010; Krueger et al., 2000; Shirokova, Osiyevskyy, \& Bogatyreva, 2016; Soliman, 2011; Shook \& Bratianu, 2010; Wang \& Wong, 2004). We used OLS in regression model which provided us deeper insight into the driving forces behind EI among Slovak youth in three rural regions. We investigated factors influencing youth's EI in three dimensions: in whole sample (Model 1), and in splat sample into respondents growing up in cities (Model 2), and those growing up in villages (Model 3).

\section{Results}

Overall composition of respondents by gender was $76.2 \%$ of girls and $23.8 \%$ boys. There were $55.4 \%$ of total positive responds of student's EI (sum of five EI construct items ranged from 5 to $10=$ high degree). Higher EI had students with city residence $(59.62 \%)$ in comparison with students from village $(51.92 \%)$. 
Table 3

Independent Variables - \% of Positive Responses

\begin{tabular}{|c|c|c|c|}
\hline \multirow[t]{2}{*}{ Variable } & \multicolumn{3}{|c|}{$\%$ of positive responses } \\
\hline & Model 1 & Model 2 & Model 3 \\
\hline Parents self-employed & $40.8 \%$ & $41.2 \%$ & $40.3 \%$ \\
\hline Relatives (other than parents) owning enterprise & $53.0 \%$ & $50.4 \%$ & $55.9 \%$ \\
\hline Friends owning enterprise & $47.6 \%$ & $44.5 \%$ & $51.0 \%$ \\
\hline Others owning enterprise & $87.9 \%$ & $85.8 \%$ & $90.1 \%$ \\
\hline Support from family and friends $(1=$ agree completely and $2=$ agree $)$ & $74.7 \%$ & $78.3 \%$ & $70.8 \%$ \\
\hline Gender (girls) & $76.2 \%$ & $75.2 \%$ & $77.4 \%$ \\
\hline Leadership $(1=$ agree completely and $2=$ agree $)$ & $46.7 \%$ & $51.3 \%$ & $41.7 \%$ \\
\hline Autonomy $(1=$ very important and $2=$ important $)$ & $91.8 \%$ & $93.0 \%$ & $90.5 \%$ \\
\hline Creativity $(1=$ very important and $2=$ important $)$ & $78.0 \%$ & $79.9 \%$ & $75.9 \%$ \\
\hline Security $(1=$ very important and $2=$ important $)$ & $97.2 \%$ & $96.9 \%$ & $97.5 \%$ \\
\hline Technical interest $(1=$ very important and $2=$ important $)$ & $21.7 \%$ & $20.4 \%$ & $23.2 \%$ \\
\hline Academic interest $(1=$ very important and $2=$ important $)$ & $66.5 \%$ & $66.2 \%$ & $66.8 \%$ \\
\hline Will to start career in birthplace $(1=$ very important and $2=$ important $)$ & $32.0 \%$ & $32.7 \%$ & $31.3 \%$ \\
\hline Village residence & $46.20 \%$ & - & - \\
\hline Proactive personality $(1=$ agree completely and 2 rather agree $)$ & $30.8 \%$ & $31.2 \%$ & $30.4 \%$ \\
\hline Entrepreneurial courses (1 yes) & $16.9 \%$ & $18.6 \%$ & $15.0 \%$ \\
\hline Entrepreneurial training (1 yes) & $45.0 \%$ & $43.3 \%$ & $46.9 \%$ \\
\hline
\end{tabular}

Table 3 composes of percentage score of positive responses of independent variables. There are no high differences between the Models. Most important among Slovak youth can be considered autonomy and security, which belong to individual factors. Above $70 \%$ of respondents considered creativity important; however, this variable does not seem to have impact on youth's EI (results in Table 4). Social capital in the form of support from family and friends seems to be very important for Slovak youth originated from 3 rural regions. Positive responses on PAP and leadership did not reach high score, but as regression results in Table 4 showed, they have significant impact on youth's EI.

Table 4 presents the results of all three regression models where we investigated significance of factors impacting on Slovak youth's EI. All models were statistically significant $(p<.001)$. The regression model for village residence (Model 3) had an overall explanatory power of 55.3\%; city residence had 42.8\% (Model 2); all respondents (Model 1) had 43.8\% power.

We can find differences in results for students living in village and living in cities. From contextual factors only support from family and friends seems to be common factor which positively influence youth's EI living in the city and village. Student's EI from villages is significantly positively influenced by role models (parents self-employed) of culture capital and friends owning enterprise of social capital, but this were not the case for students living in cities. 
Table 4

Regression Results for Model 1, 2 and 3 (dependent variable is EI)

\begin{tabular}{|c|c|c|c|}
\hline & Model 1 & Model 2 & Model 3 \\
\hline \multirow{3}{*}{ Constant } & Est. $\beta^{\mathrm{a}}$ & Est. $\beta^{\mathrm{a}}$ & Est. $\beta^{\mathrm{a}}$ \\
\hline & $-1.73 * * *$ & $-1.56^{* * *}$ & $-2.09 * * *$ \\
\hline & Est. $\beta^{\mathrm{b}}$ & Est. $\beta^{\mathrm{b}}$ & Est. $\beta^{\mathrm{b}}$ \\
\hline Parents self-employed & .04 & .004 & $.14^{* *}$ \\
\hline Other relatives owning enterprise & -.002 & -.03 & .04 \\
\hline Friends owning enterprise & $.11 * *$ & -.04 & $.24 * * *$ \\
\hline Others owning enterprise & $.09 *$ & $.18^{* *}$ & -.07 \\
\hline Support from family and friends & $.25 * * *$ & $.25 * * *$ & $.23 * * *$ \\
\hline Gender & -.06 & -.01 & -.12 \\
\hline Leadership & $.19 * * *$ & $.34 * * *$ & $.13 *$ \\
\hline Autonomy & $.10 * *$ & $.14 *$ & .03 \\
\hline Creativity & .08 & .03 & .12 \\
\hline Security & -.04 & -.09 & .05 \\
\hline Technical interest & .02 & -.02 & .03 \\
\hline Academic interest & $-.09^{*}$ & $-.14 * *$ & -.01 \\
\hline Proactive personality & $.06^{* * *}$ & $.18^{* *}$ & $.25 * * *$ \\
\hline Will to start career in birthplace & -.01 & -.06 & .08 \\
\hline Entrepreneurial course & .04 & .08 & .05 \\
\hline Entrepreneurial training & .07 & .04 & $.12 *$ \\
\hline $\mathrm{R}^{2}$ & .43 & .42 & .55 \\
\hline Valid $N$ & 537 & 289 & 248 \\
\hline ANOVA F & $12.35^{* * *}$ & $6.49 * * *$ & $8.97 * * *$ \\
\hline
\end{tabular}

From individual factors affecting EI significantly positively, we can mention leadership (stronger for city residence students) and proactive personality (stronger for village residence students). Regarding desire for autonomy, it seems to have a positive significant impact on student's EI living in cities rather than on those living in villages. The EI of Slovak rural youth will depend heavily on career anchors directed towards self-employment, such as leadership, proactive personality and autonomy. Leadership together with gaining autonomy through entrepreneurship may change a youth's position in the Slovak labor market, from being a subordinate with predesignated tasks within hierarchical structures to a free position. The insignificant correlation between creativity and youth's EI is probably caused by a necessitydriven EI where financial motives for self-employment dominate individual interests and preferences - this seems to be major differences between our results and the same way designed study in Norway by Nesse et al. (2015). Academic interests seem to have negative impact on student's EI especially for those living in cities where there are more opportunities to find jobs demanding academic education. According to Central Office of Labour, Social Affairs and Family, until 2021, industrial sectors in Slovakia will need more than 350000 new employees (UPSVAR, 2016). However, a technical skilled workforce is strongly needed in the labor market, and while the Slovak economy is focused on industrial sectors, young people do not consider technical interests as important in relation to their EI and possible future business opportunities in these sectors. 
Entrepreneurial education in current form does not have influence on youth's EI. An exception is found in the influence of entrepreneurial training on EI - this is significant only for students living in villages at the $10 \%$ level. The reason for this could be that in agricultural areas there still exist spaces for new venture creation in addition to family businesses in this sector. Despite this, our results showed that, in general, Slovak student's perceptions of their entrepreneurial education and training are that it is not sufficient for real life. Young Slovaks have quite high EI, but it seems that they lack sufficient entrepreneurial knowledge to help them to be better able to face the challenging conditions in the real economy. Therefore, this result should encourage more in-depth investigation of the inner content and structure of entrepreneurial education and training of youth in secondary-level education, at least in rural areas suffering high unemployment rates among young people. Improvements could be achieved by more initiatives from schools and teachers within the practical programme, Junior Achievement Firm, where some students' firms achieved international recognition.

\section{Conclusion}

Leadership, autonomy and proactive personality as career anchors and perceived support from family and friends are major factors explaining EI among youth in Banská Bystrica, Žilina and Prešov region. Due to higher unemployment and lower wages relative to income earned from self-employment, there seems to be a higher share of necessity-driven entrepreneurial intentions among Slovak youth, for example in comparison with Norwegian study by Nesse et al. (2015). The EI will, therefore, depend heavily on career anchors directed towards selfemployment, and to a lesser extent on their participation in current entrepreneurial education and training schemes, maybe as a consequence of former Communist policy discouraging entrepreneurship.

In many Slovak high schools, participating in entrepreneurial training schemes is a mandatory activity. Many Slovak coaches and teachers on entrepreneurial training schemes were born and raised during a Communist regime that was characterized by low entrepreneurial activity, and this may influence their skills and abilities as mentors. The general practical implications of our results for education policy makers suggest that building leadership ambitions together with building up a desire for autonomy, creativity and technical interests should be strengthened within the educational process. Techniques within entrepreneurial education may include creative business thinking skills, team working, business startups, visitation to prosperous entrepreneurial projects, hands-on entrepreneurial problem-solving exercises, role-playing, meeting successful entrepreneurs, and more broadly, active learning (Esfandiar et al., 2017).

Policy makers could implement our findings in their efforts to increase the entrepreneurial activity as a tool for reducing youth unemployment and subsequent migration. Knowledge about EI implemented in the educational process is very likely to be reflected into a higher quality of human capital as a key factor of growth and competitiveness of the national economy. It would also be useful to get more studies about different approaches to entrepreneurship education and their impact on EI and entrepreneurial activity of youth with special focus on urban and rural areas. Future research can link our findings to concrete methods within entrepreneurial education. Investigation of factors leading to entrepreneurial 
action of Slovak's youth could help to improve entrepreneurial education and training.

The present study has several limitations. The major limitation of intention-based research is that validity and stability of the link between intention and behavior can only be directly observed by longitudinal research (Davidsson \& Honig, 2003). However, entrepreneurship research would greatly profit from studies investigating the link between intention and behavior in an entrepreneurial context (Fayolle \& Liñán, 2014). There are also other ways of measuring EI (Zapkau, Schwens, Steinmetz, \& Kabst, 2015). Common limitation of this type of study is that it is derived from the self-selection bias (Miranda, Chamorro-Mera, \& Rubio, 2017). In particular, persons with a prior interest in the subject of study are more likely to be attracted to respond to such a survey. The results of this study are at least partly dependent on cultural and economic conditions in predominantly rural Slovakia and may not be universally applicable. Despite limitations of this study, it also offers valuable insight into EI of youth in predominately rural areas of Post-Communist country, and it provides several implications for decision-makers responsible for education of youth.

\section{Authors Note}

This paper was supported by project VEGA no. No.1/0621/17 "Decision-making Process of Slovak Households about Allocation of Time for Paid and Unpaid Work and Household Strategies' Impact on Selected Areas of the Economic Practice".

\section{References}

Ajzen, I., (1991). The theory of planned behavior. Organizational Behavior and Human Decision Processes 50(2), $179-211$.

Aldrich, H., (1999). Organizations evolving. London: Sage Publications.

Aldrich, H. E., \& Wiedenmayer, G. (1993). From traits to rates: An ecological perspective on organizational foundings. Advances in Entrepreneurship, Firm Emergence, and Growth, 1, 145-195.

Altinay, L., Madanoglu, M., Daniele, R., \& Lashley, C. (2012). The influence of family tradition and psychological traits on entrepreneurial intention. International Journal of Hospitality Management 31, 489-499.

Bacq, S., Alt, E. (2018, in press). Feeling capable and valued: A prosocial perspective on the link between empathy and social entrepreneurial intentions. Journal of Business Venturing. Retrieved from https://doi.org/10.1016/j.jbusvent.2018.01.004

Bao, H., Peng, Y., (2016). Effect of land expropriation on land-lost farmers' entrepreneurial action: A case study of Zhejiang Province. Habitat International 53, 342-349.

Bateman, T. S., \& Crant, J. M., (1993). The proactive component of organizational-behavior: A measure and correlates. Journal of Organizational Behavior, 14(2), 103-118.

Bell, J., Loane, S., Hegarty, C., \& Morrow, T. (2010). Embedding international entrepreneurship into postgraduate business programmes. International Review of Entrepreneurship, 8(1), 33-44.

Bourdieu P., (1986). The forms of capital. In J. G. Richardson (ed.), Handbook of theory and research for the sociology of education (241-258). New York: Greenwood Press.

Byers T., Kist H., \& Sutton R. I., (1999). Characteristics of the entrepreneur: Social creatures, not solo heros. In R. C. Dorf (Ed.), The technology management handbook, Boca Raton: CRC Press LLC.

Bygrave W.D., (2004). The entrepreneurial process. W.D. Bygrave, \& A. Zacharakis (Eds.), The portable MBA in entrepreneurship (1-26). Hoboken, NJ: John Wiley \& Sons.

Covey S. R., (2004). The 7 habits of highly effective people. Englewood Cliffs, NJ: Prentice-Hall.

Davidsson, P., \& Honig, B. (2003). The role of social and human capital among nascent entrepreneurs. Journal of Business Venturing, 18(3), 301-331.

Douglas, E. J., (2013). Reconstructing entrepreneurial intentions to identify predisposition for growth. Journal of Business Venturing 28, 633-651. 
Elert, N., Andersson, F. W., \& Wennberg, K. (2015). The impact of entrepreneurship education in high school on long-term entrepreneurial performance. Journal of Economic Behavior and Organization, 111, 209-223.

Esfandiar, K., Sharifi-Tehrani, M., Pratt, S., \& Altinay, L. (2017, in press). Understanding entrepreneurial intentions: A developed integrated structural model approach. Journal of Business Research, 1-11. Retrieved from http://dx.doi.org/10.1016/j.jbusres.2017.10.045

Fayolle, A., \& Liñán, F. (2014). The future of research on entrepreneurial intentions. Journal of Business Research, 67, 663666.

Field, J., (2003). Social capital. New York: Routledge.

Fini, R., Grimaldi, R., Marzocchi, G. L., \& Sobrero, M., (2012). The determinants of corporate entrepreneurial intention within small and newly established firms: Entrepreneurship. Theory and Practice, 36(2), 387-414.

Garavan, T. N., \& O'Cinnéide, B. (1994). Entrepreneurship education and training programmes: A review and evaluation Part I. Journal of European Industrial Training, 44(8/9), 398-404.

Gavrila-Paven, I., Dobrescu, E. M., \& Dobre, E. M. (2014). Sustainable development through entrepreneurial initiatives in Center Region, Romania. Procedia Economics and Finance 15, 1065-1070.

Goethner, M., Obschonka, M., Silbereisen, R. K., \& Cantner, U., (2012). Scientists' transition to academic entrepreneurship: Economic and psychological determinants. Journal of Economic Psychology 33(3), 628-641.

Gorman, G., Hanlon, D., \& King, W. (1997). Some research perspectives on entrepreneurship education, enterprise education and education for small business management: A ten-year literature review. International Small Business Journal, 15 (3), $56-79$.

Gray, B. J., \& Kirkwood, J. (2010). Issues in experiential entrepreneurship education - introduction to the special edition. International Review of Entrepreneurship, 8(1), 3-18.

Greve, A., (2000). Sosial kapital: Hvor står vi i dag? En kommentar til Colemans artikkel [Social capital: Where do we stand today? A comment on Coleman's article]. Magma, 3(1), 80-90.

Gurel, E., Altinay, L., \& Daniele, R. (2010). Tourism students' entrepreneurial intentions. Annals of Tourism Research, 37(3), 646-669.

Hammer, L. (2000). The additive effects of semi-structured classroom activities on student learning: An application of classroom-based experiential learning techniques. Journal of Marketing Education, 22(1), 25-34.

Hansemark, O. (1998). The effects of an entrepreneurship programme on need for achievement and locus of control of reinforcement. International Journal of Entrepreneurship Behaviour and Research, 4(1). 28-50.

Jamieson, I. (1984). Education for enterprise. In A. G. Watts, \& P. Moran (Eds.), CRAC (19-27). Ballinger: Cambridge.

Kautonen, T., Hatak, I., Kibler, E., \& Wainwright, T. (2015). Emergence of entrepreneurial behaviour: The role of age-based self-image. Journal of Economic Psychology, 50, 41-51.

Kickul J., \& Gundry L., (2002). Prospecting for strategic advantage: The proactive entrepreneurial personality and small firm innovation. Journal of Small Business Management 40(2), 85-97.

Koe, W. L., (2016). The relationship between Individual Entrepreneurial Orientation (IEO) and entrepreneurial intention. Journal of Global Entrepreneurship Research 6(13), 1-11.

Krueger, N. F., (1993). The impact of prior entrepreneurial exposure on perceptions of new venture feasibility and desirability. Entrepreneurship Theory and Practice, 18(1), 5-21.

Krueger, N. F., Reilly, M. D., \& Carsrud, A. L. (2000). Competing models of entrepreneurial intentions. Journal of Business Venturing, 15, 411-432.

Leenders, R. Th. A. J., \& Gabbay, S. M., (1999). Corporate social capital and liability. Amsterdam: Kluwer Academic Publishers.

Lin N., Cook K., \& Burt, R. S. (Eds.). (2001). Social capital. Theory and research. New Brunswick, New Jersey: Aldine Transaction.

Maes, J., Leroy, H., \& Sels, L. (2014). Gender differences in entrepreneurial intentions: A TPB multi-group analysis at factor and indicator level. European Management Journal, 32, 84-794.

Martin, B. C., McNally, J. J., \& Kay, M. J. (2013). Examining the formation of human capital in entrepreneurship: A metaanalysis of entrepreneurship education outcomes. Journal of Business Venturing, 28(2), 211-224.

Mazzarol T., Volery T., Doss N., \& Thein, V. (1999). Factors influencing small business start-ups. A comparison with previous research. International Journal of Entrepreneurial Behaviour and Research, 5(2), 48-63. 
McNaughton, R., \& Armitage, H. (2010). Developing entrepreneurs through experiential learning: The Master of Business, Entrepreneurship and Technology program at the University of Waterloo, Canada. International Review of Entrepreneurship, 8(1), 19-32.

Miller, D., (1983). The correlates of entrepreneurship in three types of firms. Management Science, 29, 770-791.

Miranda, F. J., Chamorro-Mera, A., \& Rubio, S. (2017). Academic entrepreneurship in Spanish universities: An analysis of the determinants of entrepreneurial intention. European Research on Management and Business Economics, 23, 113-122

Mueller, P., (2006). Entrepreneurship in the region: Breeding ground for nascent entrepreneurs? Small Business Economics, 27(1), 41-58.

Nesse, J.G., Årethun, T., \& Håvold, J. I., (2015). Entrepreneurial intentions among youth in rural areas: regional differences and changes over time. Proceedings of the 12th International Conference on Enterprise Systems, Accounting and Logistics, 86-107.

Nga, J. K. H., \& Shamuganathan, G. (2010). The influence of personality traits and demographic factors on social entrepreneurship start up intentions. Journal of Business Ethics, 95(2), 259-282.

Nishantha, B. (2009). Influence of personality traits and socio-demographic background of undergraduate students on motivation for entrepreneurial career: The case of Sri Lanka. Ryukoku University Economic Association, 49(2), 71-82.

Obschonka, M., Silbereisen, R. K., \& Schmitt-Rodermund, E. (2010). Entrepreneurial intention as developmental outcome. Journal of Vocational Behavior, 77, 63-72.

Ozaralli, N., \& Rivenburgh, N. K., (2016). Entrepreneurial intention: Antecedents to entrepreneurial behavior in the U.S.A. and Turkey. Journal of Global Entrepreneurship Research, 6(3), 1-32.

Pallant, J. (2011). SPSS survival manual: A step by step guide to data analysis using SPSS (4th ed.). Australia: Allen \& Unwin.

Pittaway, L., \& Cope, J. (2007). Entrepreneurship education: A systematic review of the evidence. International Small Business Journal 25(5), $479-510$.

Plaschka, G. R., \& Welsch, H. P. (1990). Emerging structures in entrepreneurship education: curricula designs and strategies. Entrepreneurship Theory and Practice, 14(3), 55-71.

Rădulescu, E., Marian, L., \& Moica, S. (2014). Innovations and opportunities for entrepreneurial rural developments. Procedia Economics and Finance, 15, 1495-1500.

Robinson, S., \& Stubberud, H. A. (2014). Elements of entrepreneurial orientation and their relationship to entrepreneurial intent. Journal of Entrepreneurship Education, 17(2), 1-12.

Schein, E. H. (1975). How 'career anchors' hold executives to their career paths. Personnel 52(3), 11-24.

Schein, E. H. (1990). Career anchors: Discovering your real values. Revised edition. San Francisco: Pfeiffer \& Company.

Sharma, L., \& Madan, P. (2014). Effect of individual factors on youth entrepreneurship - a study of Uttarakhand state, India. Journal of Global Entrepreneurship Research 2(3), 1-17.

Shirokova, G., Osiyevskyy, O., \& Bogatyreva, K., (2016). Exploring the intention-behavior link in student entrepreneurship: Moderating effects of individual and environmental characteristics. European Management Journal, 34, 386-399.

Shook, C. L., \& Bratianu, C. (2010). Entrepreneurial intent in a transitional economy: An application of the theory of planned behavior to Romanian students. The International Entrepreneurship and Management Journal, 6(3), 231-247.

Soliman, D. M. (2011). Entrepreneurial intention among tourism undergraduate students in Egypt. Tourism Analysis, 16(4), $471-481$.

Souitaris, V., Zerbinati, S., \& Al-Laham, A. (2007). Do entrepreneurship programmes raise entrepreneurial intention of science and engineering students? The effect of learning, inspiration and resources. Journal of Business Venturing, 22(4), 566-591.

Timmons, J. A., \& Spinelli, S., (2003). New venture creation: Entrepreneurship for the $21^{\text {st }}$ century. New York: McGrawHill/Irwin.

Tkachev, A, \& Kolvereid, L. (1999). Self-employment intentions among Russian students. Entrepreneurship and Regional Development, 11(3), 269-280.

UPSVAR. (2016). Medium-term forecast of the needs of the labor market to 2021. Retrieved from http://www.upsvar.sk/buxus/docs/statistic/NP_prognozy/Strednodoba_prognoza_potrieb_trhu_prace_do_roku_2021.pdf

Wang, C. K., \& Wong, P. K. (2004). Entrepreneurial interest of university students in Singapore. Technovation, 24(2), 163172.

$\mathrm{Wu}$, J. (2010). The impact of corporate supplier diversity programs on corporate purchasers' intention to purchase from women-owned enterprises: An empirical test. Business and Society 49(2), 359-380. 
Zapkau, F.B., Schwens, C., Steinmetz, H., \& Kabst, R. (2015). Disentangling the effect of prior entrepreneurial exposure on entrepreneurial intention. Journal of Business Research, 68(3), 639-653.

Zellweger, T., Sieger, P., \& Halter, F. (2011). Should I stay or should I go? Career choices of students with family business background. Journal of Business Venturing 26, 521-536.

Zhao H., Seibert S. E., \& Hills G. E. (2005). The mediating role of self-efficacy in the development of entrepreneurial intentions. Journal of Applied Psychology, 90(6), 1265-1272. 